УДК 681. 586. 73

\title{
ДОСЛІДЖЕННЯ МОЖЛИВОСТІ ТЕПЛОВІЗІЙНОГО КОНТРОЛЮ ПРИСТРОЇВ ЗАЛІЗНИЧНОЇ АВТОМАТИКИ
}

Д-р техн. наук А.Б. Бойнік, С.В. Тетерук

\section{ИССЛЕДОВАНИЕ ВОЗМОЖНОСТИ ТЕПЛОВИЗИОННОГО КОНТРОЛЯ УСТРОЙСТВ ЖЕЛЕЗНОДОРОЖНОЙ АВТОМАТИКИ}

Д-р техн. наук А.Б. Бойник, С.В. Тетерев

\section{RESEARCH OPPORTUNITIES THERMAL CONTROL DEVICES RAILWAY AUTOMATICS}

Doct. of techn. science A.B. Boynik, S.V. Teteruk

Проведено аналіз причин відмов пристроїв залізничної автоматики та дослідження способів їх діагностування методом тепловізійного контролю.

Ключові слова: тепловізіонний контроль, пристрої залізничної автоматики, відмова, тепловізор, об'єкт контролю, температура, тепловізійне зображення.

Проведен анализ причин отказов устройств железнодорожной автоматики $u$ исследование способов их диагностики методом тепловизионного контроля.

Ключевые слова: тепловизионный контроль, устройства железнодорожной автоматики, отказ, тепловизор, объект контроля, температура, тепловизионное изображение.

The analysis of the causes of failures of railway automation devices and research methods of their diagnosis by a thermal control.

Keywords: thermal control devices railway automatics, rejection, thermal, object control, temperature, Thermal Image.

Вступ. Працездатність пристроїв автоматики, телемеханіки та зв'язку на залізничному транспорті багато в чому визначається якістю вимірювань та застосуванням прогресивних методів обслуговування.

Результати вимірювань дозволяють виявити відхилення параметрів апаратури, що експлуатується, від встановлених норм і таким чином своєчасно вжити заходів для нормального іiі функціонування. Якщо врахувати, що пристрої автоматики, телемеханіки та зв'язку працюють у складних умовах, при яких необхідно забезпечити безпеку руху поїздів, то стає очевидним велике значення вимірювань параметрів розглянутих пристроїв.
Постановка проблем. В сучасних умовах економічного розвитку українських залізниць постає питання продовження терміну служби всього енергоємного обладнання, зокрема пристроїв залізничної автоматики (3А) i телемеханіки. Тi капіталовкладення, які здійснюються в теперішній час, $\epsilon$ незначними i не вирішують загальної проблеми надійної експлуатації електрообладнання, яке в переважній більшості було введено в роботу ще в радянські часи.

Очевидно, що повне зняття 3 експлуатації електрообладнання, яке відпрацювало нормативний термін, неможливе, враховуючи те, що воно знаходиться в задовільному стані і може 
працювати ще деякий час. 3 іншого боку, експлуатація такого обладнання $\epsilon$ небезпечною і може мати важкі наслідки. Тому постає питання експлуатації електрообладнання за технічним станом, що передбачає здійснення його діагностування в процесі роботи.

Для діагностування електрообладнання застосовуються різні методи та засоби. Як показує досвід, не існує єдиних підходів до визначення технічного стану того чи іншого виду електрообладнання. В деяких випадках таке діагностування взагалі здійснити неможливо.

Мета роботи. Дослідження можливості тепловізійного контролю пристроїв 3А та способів їх теплового діагностування.

Аналіз останніх досліджень i публікацій. Сьогодні існує велика кількість як вітчизняних, так і закордонних робіт, в яких розглядаються аспекти теорії, побудови i застосування різних видів пристроїв контролю нагрівання об'єктів. Відомо, що в багатьох випадках для визначення технічного стану електрообладнання його необхідно виводити 3 роботи. Аналіз робіт цієї тематики свідчить, що одним із підходів до діагностування електрообладнання, який особливо інтенсивно розвивається останніми роками, $\epsilon$ застосування тепловізійних методів визначення технічного стану електрообладнання. Переваги такого підходу очевидні, оскільки тепловізійні методи придатні для виявлення дефектів будь-якого електрообладнання дистанційно та без виведення його з роботи.

Основний матеріал. У період з 2008 по 2012 роки у господарствах сигналізації та зв'язку було допущено 26540 відмов пристроїв 3А.

В 2008 році кількість відмов пристроїв СЦБ склала 5547, що на 19,2 \% менше, ніж у 2007. Кількість відмов у 2009 році склала 5177, тобто зменшилась на $6,7 \%$ у порівнянні 3 2008. Однак у 2010 році кількість відмов зросла на 16,2 \% по відношенню до показників 2009 року. За 2011 рік вдалося зменшити кількість відмов до 4837, тобто на $19,6 \%$. Кількість відмов за 2012 рік збільшилась на 2,6\% і склала 4963 випадки проти 4837 у порівнянні 3 2011 роком [1-5].

Проте аналіз пошкоджень пристроїв СЦБ, які були віднесені за господарствами сигналізації та зв'язку, свідчить, що їх кількість не зменшилась.

У 2008 та 2009 роках кількість відмов пристроїв СЦБ у порівнянні з попередніми роками вдалося зменшити, а в 2010 році кількість відмов відносно 2009 року зросла на 7,5 \%. Найбільша кількість відмов - на Придніпровській залізниці (358).

Протягом 2011 року кількість пошкоджень 3 вини господарства сигналізації та зв'язку зросла в порівнянні 3 2010 роком на 5,8 \% та склала 1515 відмов. При цьому найбільша кількість відмов - на Придніпровській залізниці (336).

Кількість відмов у 2012 році у порівнянні з 2011 роком збільшилась на 2,4 \% і склала 1552 проти 1515. Найбільше відмов допущено на Придніпровській залізниці (342) [5].

Аналіз відмов пристроїв СЦБ, віднесених за господарством сигналізації та зв'язку, у 2012 році свідчить, що основними об'єктами відмов пристроїв СЦБ є:

1) вихід 3 ладу реле, блоків, трансформаторів, випрямлячів, безконтактної апаратури, пристроїв захисту. Основні причини відмов апаратури - вихід 3 ладу резисторів, напівпровідникових елементів, конденсаторів, обрив обмоток;

2) несправність в релейних шафах, на стативах, в колійних коробках. Основні причини відмов: втрата контакту в рознімачах, неякісне паяння, несправність штепсельних плат;

3) порушення роботи рейкових кіл. Основні причини відмов у рейкових колах - обрив дросельних перемичок i з'єднувачів; 
4) порушення роботи кабельних ліній. Основні причини відмов кабельних ліній обрив, пошкодження кабелів при виконанні робіт;

5) несправність стрілочних електроприводів, гарнітури, замків Мелентьєва.

Основними причинами відмов пристроїв СЦБ (таблиця) є:

1) експлуатаційні - 1322 відмови, або $85,2 \%$ від усіх відмов (найбільша кількість таких відмов на Одеській залізниці - 243 відмови);

2) відмови 3 інших причин - 230 відмов, або $14,8 \%$ від усіх відмов (найбільше таких відмов на ПівденноЗахідній залізниці - 51 відмова).

При цьому 3 вини обслуговуючого персоналу сталося 830 відмов.

Співвідношення відмов пристроїв СЦБ за причинами у 2012 році

\begin{tabular}{|l|c|}
\hline \multicolumn{1}{|c|}{ Причини відмов } & $\begin{array}{c}\text { Кількість } \\
\text { відмов, \% }\end{array}$ \\
\hline Основні: & 53,5 \\
- порушення технології виконання робіт при ТО та ремонті пристроїв & \\
СЦБ; & 18,4 \\
- вихід з ладу приладів, пристроїв через фізичне старіння; & 4,6 \\
- неякісний ремонт та перевірка приладів у РТД СЦБ; & 7,2 \\
\hline - причина не виявлена & \\
\hline Інші: & 9,2 \\
- вплив грозових та комутаційних перенапруг; & 4,5 \\
\hline
\end{tabular}

У 2012 році середній час усунення відмов пристроїв СЦБ, віднесених за дистанціями сигналізації та зв'язку, склав 1 год 26 хв проти 1 год 25 хв у порівнянні 3 2011 роком. Найбільший середній час усунення відмов на Південно-Західній залізниці - 1 год 40 хв, а найменший серед- ній час усунення відмов на Одеській залізниці - 1 год 11 хв, що говорить про необхідність удосконалення системи ТО [5].

Співвідношення загальної кількості відмов пристроїв СЦБ до кількості відмов 3 причини теплового перегрівання наведено на рис. 1.

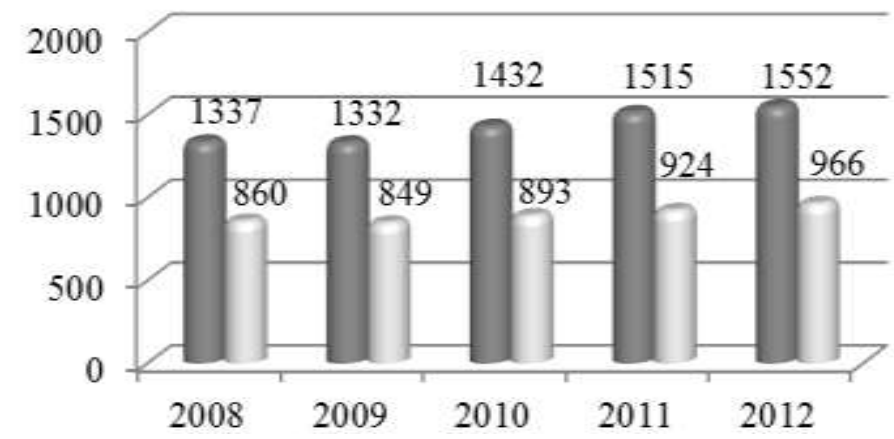

вЗагальна кількість відмов пристроїв СЦБ

曰Кількість відмов 3 причини теплового перегрівання

Рис. 1. Співвідношення загальної кількості відмов пристроїв СЦБ до кількості відмов 3 причини теплового перегрівання за період 2008-2012 років 
Основні причини теплового нагрівання такі: зменшення опору ізоляції електричних кіл, перевищення амплітуди робочих струмів, збільшення перехідного опору контактів реле і перемикачів, зміна параметрів напівпровідникових елементів і т.д.

Для виявлення та попередження відмов пристроїв ЗА слід використовувати метод тепловізійного діагностування. Це найсучасніший, високоефективний i перспективний напрямок у діагностиці станів i властивостей різноманітних об'єктів. Тепловізор служить для приймання сигналів в інфрачервоній (IЧ) області спектра (теплове випромінювання) i перетворення їх у видимі зображення.

Специфіка методу полягає в його універсальності, яка обумовлена тим фактом, що інформативним якісним параметром досліджуваних об'єктів є температура. Температура служить невід'ємним індикатором роботи технічних установок i складних систем, а також характеризує структурні та теплові процеси в конструкційних матеріалах. Розшифровка температурних розподілів надає інформацію про різноманітні процеси, що протікають в об'єктах контролю.

Нескануючі тепловізійні системи засновані на використанні багатоелементних приймачів випромінювання, так званих “спостерігаючих" матриць, тобто матриць, число елементів яких дозволяє сформувати повноформатний телевізійний кадр 3 хорошим просторовим розділенням. У цих тепловізійних системах відсутні механічні вузли сканування. Більшість сучасних тепловізійних приладів побудовано за цим принципом, i у зв'язку 3 успіхами в технології виробництва матричних приймачів випромінювання не тільки не поступається, але навіть перевершує прилади 3 механічним скануванням за споживчими властивостями. На рис. 2 подана узагальнена функціональна схема тепловізора $з$ фокальною ІЧ матрицею.

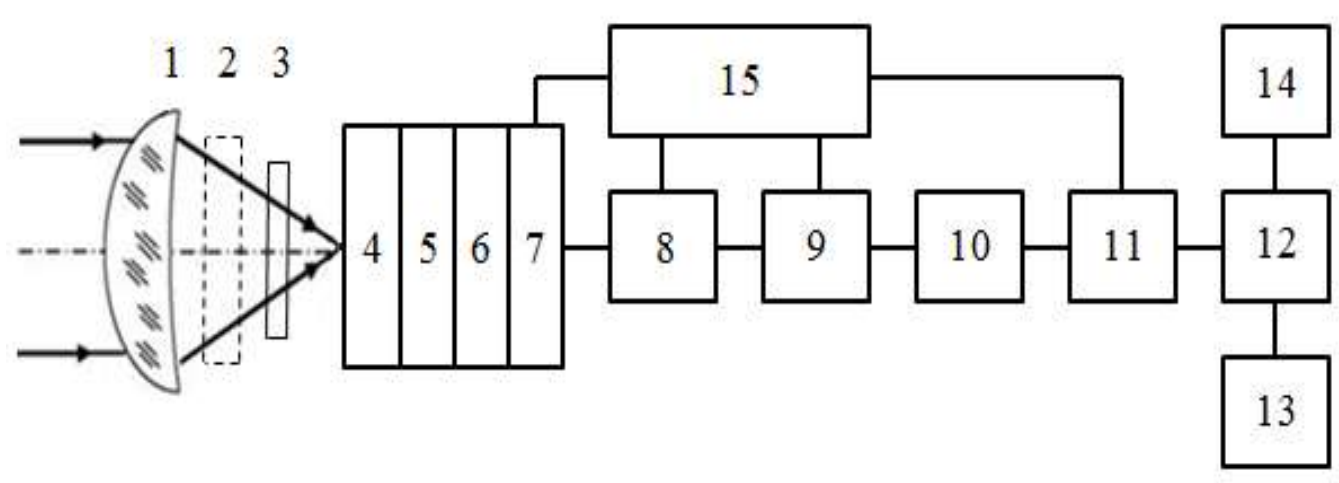

Рис. 2. Функціональна схема тепловізора на “спостерігаючій” матриці

Основні елементи тепловізора: 1 об'єктив, 2 - почорнений затвор, 3 - фільтр, 4 - детекторна матриця, 5 - попередні підсилювачі, 6 - інтегратори, 7 - мультиплексор, 8 - аналоговий коректор неоднорідності сигналів чарунок, 9 - аналогоцифровий перетворювач, 10 - цифровий коректор неоднорідності, 11 - коректор непрацюючих чарунок, 12 - формувач зображення, 13 - дисплей, 14 - цифровий вихід, 15 - тактовий генератор.

Принцип роботи тепловізора можна описати наступним. ІЧ випромінювання від нагрітих об'єктів спостереження та фонів проходить через атмосферу і потрапляє в оптичну систему приладу. Об'єктив 1 формує на фоточутливій матриці 4 зображення об'єкта, випромінювання якого проходить через інтерференційний фільтр 
3. Фотострум кожного чутливого елемента детекторної матриці 4 посилюється передпідсилювачем 5 і накопичується протягом кадру в інтеграторі (ємності) 6, який виконує роль низькочастотного фільтра, а потім надходить на мультиплексор 7. Ці елементи матриці виготовляють в інтегральному виконанні в одному блоці i розміщують при охолодженні в кріостаті. Далі слідує комп'ютерна обробка сигналів, які спочатку направляються в неохолоджувану аналогову схему обробки 8 , де відбувається попередня корекція неоднорідності чутливості, фонового і темнового струмів осередків матриці. Потім аналогові сигнали перетворяться в цифрові 9 і надходять в цифрову схему коригування 10 . Після цього віднімають непрацюючі чарунки 11, замінюють сигнал на місці непрацюючої чарунки інтерпольованим між прилеглими осередками i направляють в блок формування зображення 12. На виході інформація виводиться на дисплей 13, а також видається в цифровому вигляді 14 [7].

Важливою функцією теловізорів $\epsilon$ моделювання тепловізійних зображень. Аналіз поляризації тепловізійних зображень об'єктів показав, що матеріал, 3 якого виконаний досліджуваний об'єкт, впливає на яскравість поляризаційних зображень. Як наслідок, необхідно враховувати вплив оптичних властивостей поверхні досліджуваних об'єктів на значення кута для всіх елементів поляризаційних термограм (рис. 3).

Метод моделювання тепловізійних зображень, рівень відеосигналів у яких визначається виразом (1), дозволяє розпізнати об'єкти усередині їх контуру [10].

$$
U(N, L)=\left(\frac{1}{\pi}\right) \cdot \varepsilon(\psi) \cdot \omega \cdot \cos \psi(N, L) d S(N, L) \int_{\lambda_{1}}^{\lambda_{2}} S_{\lambda} \cdot W(\lambda, T, y, z) \cdot \tau_{0}(\lambda) \cdot \tau_{a}(\lambda) d \lambda,
$$

де $\omega$ - передній апертурний кут системиприймача тепловізора;

$$
\psi \text { - кут між нормаллю до елемента } d S(N \text {, }
$$

$L)$ поверхні об'єкта і напрямом спостереження;

$W(\lambda, T, y, z)$ - спектральна світимість елемента $d S(N, L)$ поверхні об'єкта, що має абсолютну температуру $T$;

$\varepsilon(\psi)$ - індикатриса спектрального коефіцієнта випромінювання поверхні об'єкта;

$S \lambda$ - абсолютна спектральна чутливість приймача випромінювання тепловізора;

$\lambda 1, \lambda 2$ - межі спектральної чутливості приймача випромінювання;

$\tau_{o}(\lambda), \tau_{\mathrm{a}}(\lambda)-$ спектральний коефіцієнт пропускання оптичної системи i шару атмосфери; $y, z$ - координати елемента $d S(N, L)$ поверхні об'єкта у просторі предметів.

Актуальним також $\epsilon$ вирішення проблеми виявлення об'єктів на слабко контрастних тепловізійних зображеннях. Проблеми виявлення об'єктів виникають внаслідок потенційно слабкої їх контрастності, низького рівня помітності і наявності шумів. Обробка зображень проводиться в реальному масштабі часу. Основними способами обробки зображень $\epsilon$ алгоритми цифрового шумозаглушення, накопичення сигналів, підвищення контрастності, сегментації, підкреслення меж тощо.

Вірогідність правильного виявлення сигналу об'єкта на фоні шумів визначається як [10]:

$$
F=\int_{U_{0}}^{\infty} u \cdot I_{0}(q u) \cdot e^{-\left(u^{2}+q^{2}\right) / 2} d u
$$




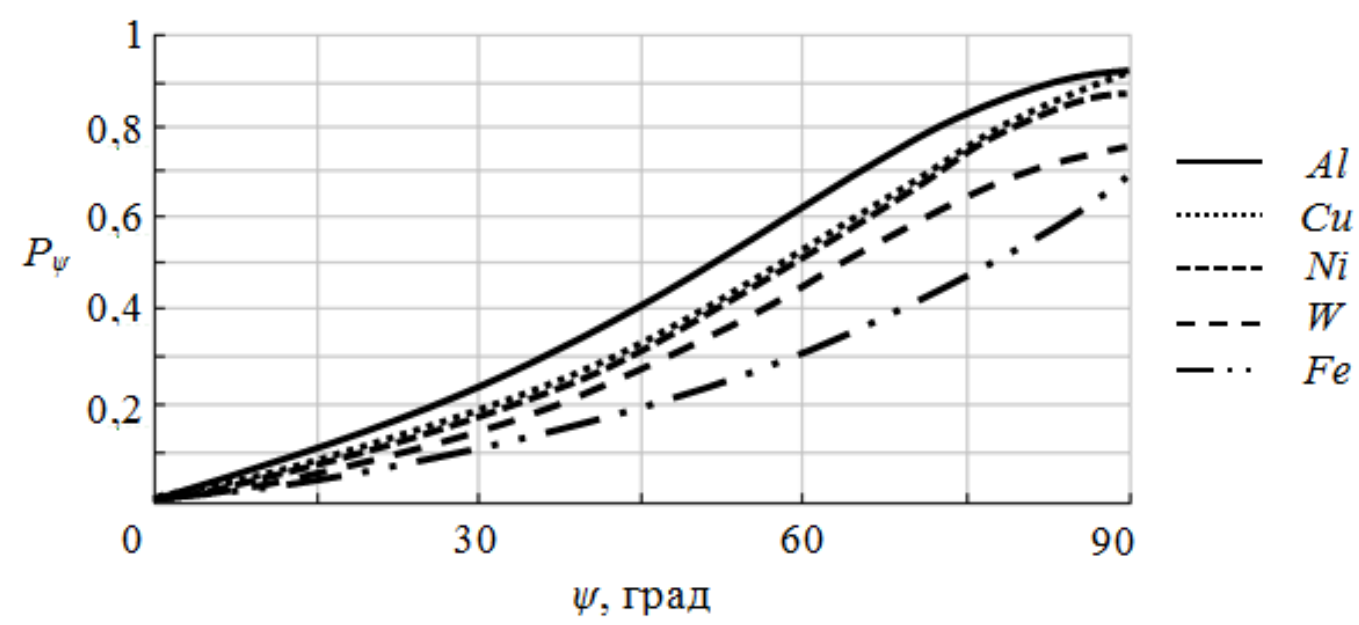

Рис. 3. Залежність ступеня поляризації $P_{\psi}$ від кута $\psi$ власного випромінювання для металевих об'єктів

Дослідження тепловізійного контролю в режимі ручного використання свідчить про те, що існують певні недоліки, характерні для більшості відомих методів контролю, а саме “людський фактор”. Вони знижують достовірність, об'єктивність і продуктивність результатів контролю, а оскільки об'єкти електрообладнання контролюються в комплексі (до декількох сотень об'єктів одночасно), то завдання підвищення достовірності 3 одночасним збільшенням продуктивності та об'єктивності контролю виходить на перше місце.

У зв'язку з цим, доцільно використовувати метод автоматизованого процесу теплового контролю електроустаткування. Одним 3 основних етапів контролю $є$ автоматичне виявлення потенційно небезпечних ділянок у великому масиві аналізованих об'єктів, їх вибірка, ідентифікація та класифікація. Для елемента, що діагностується, залежно від його типу, технічних особливостей та режиму роботи визначається оптимальне порогове значення (знаходження мінімуму, який відповідає оптимальному положенню порогу), тобто розмежовуються якісні та аномальні зони.

На наступному етапі відбувається зіставлення передбачуваних дефектів (аномальних 3он) 3 еталонними зразками дефектів шляхом порівняння термограм по контрольних точках або областях 3 подальшим аналізом за відомими критеріями дефектності.

У результаті автоматизованого контролю виключаються помилки обслуговуючого персоналу, зменшується періодичність контролю устаткування, з'являється можливість прогнозування станів контрольованих пристроїв, а також пожежної безпеки приміщення.

Висновок. Традиційні методи контролю електроустаткування, як правило, орієнтовані на необхідність тимчасового виведення його 3 роботи. На відміну від них тепловізійна діагностика дозволяє виконувати поелементну, а також загальну оцінку технічного стану електрообладнання в процесі його роботи, виявляти велику кількість дефектів на ранній стадії їх розвитку, а також визначати прийнятні експлуатаційні обмеження,

перешкоджають розвитку дефектів.

Результати досліджень свідчать, що за пристроями 3А необхідно вести постійне спостереження, що стає можливим при використанні автоматизованого способу контролю нагрівання. 


\section{Список використаних джерел}

1. Аналіз експлуатаційної роботи господарств галузі автоматики, телемеханіки та зв’язку Укрзалізниці за 2008 рік [Текст] / Державна адміністрація залізничного транспорту України. - К., 2009. - 63 с.

2. Аналіз експлуатаційної роботи господарств галузі автоматики, телемеханіки та зв'язку Укрзалізниці за 2009 рік [Текст] / Державна адміністрація залізничного транспорту України. - К., 2010. - 64 с.

3. Аналіз експлуатаційної роботи господарств галузі автоматики, телемеханіки та зв'язку Укрзалізниці за 2010 рік [Текст] / Державна адміністрація залізничного транспорту України. - К., 2011. - 65 с.

4. Аналіз експлуатаційної роботи господарств галузі автоматики, телемеханіки та зв’язку Укрзалізниці за 2011 рік [Текст] / Державна адміністрація залізничного транспорту України. - К., 2012. - 62 с.

5. Аналіз експлуатаційної роботи господарств галузі автоматики, телемеханіки та зв’язку Укрзалізниці за 2012 рік [Текст] / Державна адміністрація залізничного транспорту України. - К., 2013. - 71 с.

6. Бойник, А.Б. Диагностирование и прогнозирование состояния систем железнодорожной автоматики [Текст] / А.Б. Бойник; Залізн. трансп. України. - 2002. - № 4. C. 2-7.

7. Афонин, А.В. Основы инфракрасной термографии [Текст] / А.В. Афонин, Р.К. Ньюпорт, В.С. Поляков [и др.] // ПЭИПК. - СПб., 2004. - 240 с.

8. Тымкул, О.В. Методика определения объемной формы объектов на основе поляризационной комбинированной термограммы [Текст] / О.В. Тымкул, В.М. Тымкул, О.К. Ушаков // Оптический журнал. - 1999. - Т. 66. - № 2. - С. 54-59.

9. Выров, В.Б. Современные методы обработки сигналов [Текст] / В.Б. Выров, Ф.Н. Бузылёв, А.В. Герасимов [и др.] // Нелинейный мир. - 2010. - Т. 8, № 5. - С. 432-435.

10. Мисюк, Ю.П. Підвищення якості зображень тепловізійних засобів візуального спостереження охорони державного кордону [Текст] / Ю.П. Мисюк // Світлотехніка та теплоенергетика: наук.-техн. зб. - К.: НДІ ДПСУ, 2012.

11. Тарасов, В.В. Инфракрасные системы «смотрящего» типа [Текст] / В.В. Тарасов, Ю.Г. Якушенков // Логос. - М., 2004. - 444 с.

Бойнік Анатолій Борисович, д-р техн. наук, професор, завідувач кафедри автоматики та комп'ютерного телекерування рухом поїздів

Тетерук Сергій Вікторович, слухач групи МЗ-АТЗ-АКСУРП-Б-11, ХЦПО, начальник сектору інформаційних технологій

Boynik A.B., doct. of techn. science, Teteruk S.V. 